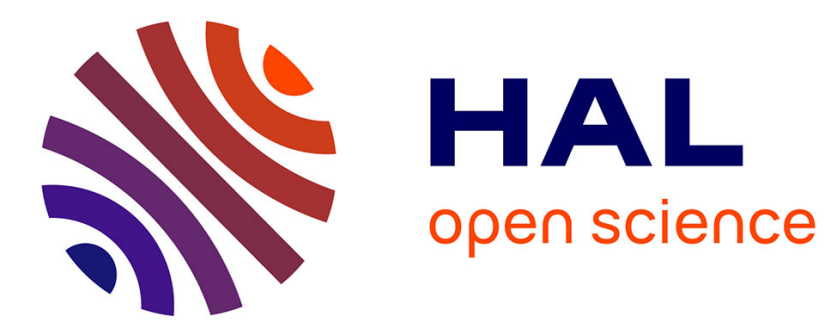

\title{
Fragmentation and immiserising specialisation : the case of the textile and clothing sector
}

Céline Gimet, Bernard Guilhon, Nathalie Roux

\section{To cite this version:}

Céline Gimet, Bernard Guilhon, Nathalie Roux. Fragmentation and immiserising specialisation: the case of the textile and clothing sector. 2010. halshs-00464393

\section{HAL Id: halshs-00464393 \\ https://shs.hal.science/halshs-00464393}

Submitted on 17 Mar 2010

HAL is a multi-disciplinary open access archive for the deposit and dissemination of scientific research documents, whether they are published or not. The documents may come from teaching and research institutions in France or abroad, or from public or private research centers.
L'archive ouverte pluridisciplinaire HAL, est destinée au dépôt et à la diffusion de documents scientifiques de niveau recherche, publiés ou non, émanant des établissements d'enseignement et de recherche français ou étrangers, des laboratoires publics ou privés. 
Fragmentation and immiserising specialisation: the case of the textile and clothing sector

Céline Gimet, Bernard Guilhon, Nathalie Roux

Mars 2010 


\section{GATE Groupe d'Analyse et de Théorie Économique Lyon-St Étienne}

93, chemin des Mouilles 69130 Ecully - France

Tel. +33(0)4 72866060

Fax $+33(0) 472866090$

6, rue Basse des Rives 42023 Saint-Etienne cedex 02 - France

Tel. +33 (0)4 77421960

Fax. $+33(0) 477421950$

Messagerie électronique / Email : gate@gate.cnrs.fr

Téléchargement / Download : http://www.gate.cnrs.fr - Publications / Working Papers 


\title{
Fragmentation and immiserising specialisation: the case of the textile and clothing sector
}

\author{
Céline GIMET ${ }^{\mathrm{a}}$, Bernard GUILHON ${ }^{\mathrm{b}}$, Nathalie ROUX ${ }^{\mathrm{c}}$
}

\begin{abstract}
With production activity tending rapidly towards international fragmentation, this study examines the consequences for labour countries of the forms of specialisation brought about by fragmentation processes. It further addresses the risk that fragmented sectors may become excluded from greater developments within the manufacturing industry as a whole. An empirical analysis using panel data reveals that, contrary to expectation, the textile and clothing sector in labour countries does not always reap the positive benefits of this form of international trade integration. Rather, we observe a phenomenon of immiserising specialisation, due to a drop in relative wages within this sector.
\end{abstract}

Keywords: offshoring, outsourcing, fragmentation, immiserising specialisation, relative wages., textile and clothing sector

JEL Classification: F14, F16, L23, L67

\footnotetext{
${ }^{a}$ Group for Economic Analysis and Theory (GATE), University of Lyon 2, CNRS UMR 5824, 93 chemin des Mouilles, 69130 Ecully, France. Tel: +33437376 282. Fax:+33437376 024. Email: gimet@gate.cnrs.fr

${ }^{\mathrm{b}}$ DEFI EA 4265 , Faculty of Economics and Management, University of the Mediterranean, Château Lafarge, route des Milles, 13290 Aix-en-Provence, France. Tel: +33 442935 993.Fax: +33 442389 585. Email: bernard.guilhon@univmed.fr.

${ }^{c}$ DEFI EA 4265, Faculty of Economics and Management, University of the Mediterranean, Château Lafarge, route des Milles, 13290 Aix-en-Provence, France. Tel: +33 442935 993.Fax: +33 442389 585. Email : nathalie.roux@univmed.fr.
} 


\section{Introduction}

A greater and greater proportion of global production is being integrated into fragmented systems of production. The globalisation of economic activity is observable not only with respect to targeted markets, but also in terms of the organisation of production (Hayter 2004). The integration of countries into global value chains has a significant impact on their specialisation structures with regards to trade. Within this framework, the least developed countries (labour countries) are seeing their workforces dominated by unskilled labour, while wealthier countries are becoming specialised in more highly-skilled activities.

Traditional approaches to international trade are based on the idea that economic openness has a positive impact on growth while equalising labour cost. With the introduction of fragmented production processes into empirical and theoretical models, the debate has tended to focus on the wage gap between skilled and unskilled workers in developed countries. The standard premise is that, within this new fragmented global production framework, the labour countries necessarily stand to benefit from higher-level employment and better wages (Rodriguez-Clare 2009). However, it appears that the short-term positive effects observed in fragmented sectors tended to overshadow the need to examine the long-term effects of integrating developing economies into international trade in this fashion.

It is therefore essential to investigate the consequences of the forms of specialisation brought about by fragmentation processes in the labour countries, while also assessing the risks of fragmented sectors becoming excluded from broader developments within the manufacturing industry as a whole. This article aims to elucidate this issue from the angle of relative wages. Wages within a single sector which are below the manufacturing industry average indicate both lower-skilled labour and decreased worker negotiation power. To express this phenomenon, we are advancing the notion of immiserising specialisation, an extension of the concept of immiserising growth as theorised by Bhagwati (1958). It should, however, be noted that the underlying mechanisms giving rise to the immiserisation process are somewhat different ${ }^{1}$. Specialisation is considered to be immiserising in cases where countries' participation in globalised production systems fails to foster virtuous growth through added value creation, more highly-skilled labour and increased productivity.

This study focuses on the textile and clothing sector for two main reasons. First, certain features of the clothing industry (unqualified work intensive, using simple technology and operating in contestable markets) have made it accessible to many developing countries (Nordàs 2004; Brenton and Hoppe 2007). This sector was fundamental in opening these countries up to international trade, since it generated the income necessary to finance productive and complementary activities within this area or in industries generating more added value. In addition, the international fragmentation of production is particularly advanced in the textile and clothing sector, making it favourable to cross exchange with the most developed countries (Kimura and Ando 2005).

\footnotetext{
${ }^{1}$ Immiserising growth is based on a direct link between a decrease in terms of trade and production growth failing to compensate this loss. Immiserising specialisation, however, can co-exist with improved terms of trade for developing countries due to drops in international prices of manufactured goods (Rodriguez-Clare 2009).
} 
However, in a context of rising international competitive pressure, the key role played by this sector in labour country development may today appear questionable, given the phenomenon of immiserising specialisation.

This article aims to show that in targeting a reduced production segment, such as the clothing industry, labour countries become locked into a form of immiserising specialisation, which may be observed in the decline in relative wages in the sector.

This study is divided into two sections. The first addresses this issue from a theoretical point of view, by analysing the fragmentation process and its consequences for relative wages. The second section focuses on the empirical validation of immiserising specialisation within this sector using a panel data model.

\section{Theoretical background}

Research seeking to explain growth in intermediary product trade has made use of a wide variety of terminology. ${ }^{2}$ The diverse range of vocabulary employed to describe a single phenomenon shows that the dynamics of these new internationalised production trends are based both on macro-economic mechanisms, as is held within international trade theories focused on country characteristics (Feenstra and Hanson, 1996; Grossman and Helpman.,2005; Antràs. and Helpman, 2004; Deardorff, 1998; Jones and Kierzkowski, 1997), and on industrial and/or sector-based processes related to firm strategy (Gereffi 1996 1999; Sturgeon 2006; Sturgeon et al. 2008). Fragmentation introduces a dual logic whereby a sector belongs both to a domestic production system and to a global value chain, headed by leading firms. The potential outcome of this duality is somewhat ambiguous.

\subsection{Fragmented stages of production}

According to conventional international trade theory, countries specialise in sectors in which they obtain relative advantages giving rise to industrial trade possibilities due to differences in factor endowments or productivity. Early research on fragmentation processes was based on conventional international trade theory, and shows that the vertical disintegration of production is driven by the law of comparative advantages (Jones and Kierzkowski 2001). In this case, trade flows are determined by input price differences.

However, there are two arguments which undermine this premise. First, traditional international trade theory has difficulty accounting for the fact that fragmentation processes give rise to intratrade flows or even to vertical trade at the intra-product level (Kimura and Ando 2005) among countries with different factor endowments (Zeddies 2007). This would suggest that a country could obtain a relative advantage in one production segment while having a relative disadvantage in terms of the final product. Second, the very notion of relative advantage could be

\footnotetext{
2 Outsourcing (Feenstra et Hanson 1996; Grossman and Helpman 2005), global sourcing (Antràs and Helpman 2004), offshoring (Baldwin and Robert-Nicoud 2007), fragmentation of production (Deardorff 1998; Jones and Kierzkowski 2001; Helg and Tajoli 2004.), vertical specialisation (Hummels et al. 2001), global value chains (Gereffi 1996 1999; Sturgeon et .al .2008; Sturgeon 2006).
} 
challenged in light of globalised production networks (Zeddies 2007), activity sector (Antràs and Helpman 2004), technological characteristics of products (Acemoglu et al. 2007), the technological complexity of production processes (Lall et al. 2004) and their technical divisibility (Nordàs, 2008). Comparative advantages related to factor prices only function if partners can offer specific expertise.

Internationalised production based on a globalised coordination system (Gereffi 1994 1999), requires that different phases of production within several countries be organised in a specific fashion. However, there is no reason to assume that domestic firms' participation in international production networks, and the form of specialisation that thus occurs, always result in the harmonious development of local production systems. They may also be a source of conflict both in terms of surplus sharing and with regards to the coherence of local production. Thus, if the division of labour organised within the value chain encourages labour countries to specialise in largely unqualified work, there is reason to believe that, given the current state of international competition, these countries will be unable generate the means to improve their added value creation, perhaps leading to "job content impoverishment" (Bottini et al.; 2007).

\subsection{Consequences for relative wages}

The effects of offshoring on unqualified workers' wages are comparable to technological change, and there are three elements determining the cost of unskilled labour: negative demand effect, negative relative price effect and positive productivity effect; the third offsets the damaging consequences of the first two in wealthy countries (Grossman and Rossi-Hansberg 2006).

Most previous empirical research on the consequences for the labour market and wages of production segment outsourcing to low-wage countries has focused on developed countries (Egger 2006) and on developments in the relationship between skilled and unskilled labour (Feenstra and Hanson 1996; Kohler 2001 2004; Jones and Kiezkowski 2001; Grossman and Rossi-Hansberg 2006 2008; Baldwin and Robert-Nicoud 2007). Munch and Skaksen (2009) analyze the relative impact of domestic and foreign outsourcing on wages in the Danish labour market. They conclude that domestic outsourcing induces a 'pure division of labour effect', thereby increasing wages for each category of workers. However, they also show that unskilled workers suffer more than skilled workers in the case of international outsourcing.

Authors have not been able to reach a theoretical consensus in this area, since results have shown both a rise and a fall in unqualified workers' wages in wealthy countries (Jones and Kierzkowski 2001; Kohler 2001 2002). Gains or losses with respect to unqualified workers' wages depend on the interaction of several factors. For certain authors, for example, outsourcing significantly contributes to reinforcing the wage gap between skilled and unskilled workers (Helg and Tajoli 2004; Bottini et al. 2007; Feenstra and Hanson 2001). This view is not shared by Ekholm and Ulltveit-Moe (2007), who hold that increased competition effect decreases the salaries of qualified workers. Furthermore, industry effect can override skilled labour effects. In this case we observe no negative effects for outsourcing on unskilled workers' salaries within the high-skill-intensive industries (Geishecker and Görg 2005). 
However, little research has been carried out regarding the consequences integrating less developed countries ${ }^{3}$ into fragmentation processes. The application of theoretical models for international trade suggests that when production processes become more vertical, and international trade volume increases, there are overall positive effects for the entire world economy and that fragmentation can foster the equalisation of factor costs (Deardorff 2001). Most studies in this area have thus predicted an increase in the relative wages of nonqualified workers in the south (Egger and Stehrer 2003). Labor cost is a key element in the relative advantage proposed by labour countries, which are generally considered to benefit from this new international division of labor. By becoming manufactured products exporters, they undergo short-term positive effects on employment and wages. Within this virtuous dynamic, local firms can absorb new technologies and develop qualifications so as to increase their competitiveness on the global markets.

However, these positive effects may be reversed when viewed from a long-term perspective, where issues of production factor reallocation come into play (Rodriguez-Clare 2009 ${ }^{4}$ ). Offshoring allows richer countries to reallocate a large part of their resources to research, which has a positive effect on wages as long as the rate of reallocation is not inferior that of fragmentation. However, by participating more and more actively in offshoring operations, the least developed countries reallocate their production to sectors integrated into verticalised production processes, to the detriment of research activity. Moreover, pressure exerted by leading firms on wages and working conditions have a deregulating effect on the local labour market, thereby reducing the negotiation power of workers (Hayter 2004). These countries thus contribute to reinforcing a form of specialisation which causes the depreciation of real wages in the longterm.

\section{Empirical validation}

The goal of this study is to carry out an empirical analysis of the impact on relative wages (as compared with a country's average industrial wage in the textile and clothing sector) of integrating workers from low-income countries (labour countries) into global production processes. Relative wages represent both cost variables (relative advantages play a role where strategy is constrained by leading firms) and income variables expressing a sector's rise or fall with respect to the manufacturing industry average ${ }^{5}$. Investment, employment, productivity and firms positioning variables are integrated into stages of production in order to explain the performance of relative wages. Differences observed among subsectors (upstream for the textile sector, downstream for the clothing industry) elucidate the importance of consistency in development throughout the sector.

\footnotetext{
${ }^{3}$ A seminal study by Feenstra and Hanson (1997) revealed the positive impact of direct investment flows on the wages of skilled workers in Mexico.

4 Rodriguez-Clare's model (2009) focuses more on the effect of offshoring on average wages than on the distribution of wages between skilled and unskilled labour.

${ }^{5}$ A decrease in relative wage does not necessarily imply a drop in real wage.
} 


\subsection{Methodology}

This study is based on a panel data analysis combining time series and cross-sectional data, so as to differentiate countries by taking individual constants into account. The use of panel data brings out individual heterogeneity and allows for higher-level information, while also enabling the measurement and identification of effects not easily detected using time series data or crosssectional analysis.

This study uses a sample of 18 countries $^{6}$ over the 1990-2005 period. Countries are selected based on the historic weight of the sector and on its current size with respect to total manufactured production. The sample has been divided into two groups of countries based on GDP per inhabitant?: economies with relatively higher incomes $(I C)$ and others $(E C)$. The appended tables (see appendices 1,2 and 3) bring out the relative size of the textile and clothing sector for both groups of countries. In general, $I C$ countries tend to be less specialised in the textile and clothing sector than $E C$ countries $^{8}$. Many $I C$ countries having previously specialised in this sector were able to develop their relative advantages during the first waves of delocalisation. The export income they gained from this initial specialisation enabled them to diversify their industrial activity towards sectors generating more added value. During the observation period, certain countries have progressively withdrawn from the sector (Malaysia, Korea, Singapore, Cyprus) while others have developed this overall industry. However, the lower-income countries $(E C)$ tend to specialise, for the most part, in clothing-related activity (Bulgaria, Indonesia, Jordan, Philippines, Romania, Tunisia). Among these countries, India, Indonesia and, to a lesser extent, Tunisia, have developed upstream activity in the textile sector. The differences in results among $E C$ and $I C$ reflect these specialisations.

The dependent variable is relative wage, that is, the relationship between the average textile and clothing sector wage and the average manufacturing sector wage. The global dependant variable wage-textile-clothing, representing the relative textile and clothing industry wage, is split into two sub-variables: the wage-cloth variable represents relative wage solely in the production of clothing items, and the wage-text variable represents the textile industry relative wage. This is a means of bringing out differences in the impact of specialisation for various stages of production and taking into account specific effects within the textile and clothing subsectors.

17 independent variables are broken down into four categories (see table 1). The goal is to differentiate countries' stages of specialisation in textile and clothing according to whether or not they produce primarily intermediary products (fabrics, text) or final products (clothing, cloth). It is supposed that specialisation upstream in the production process will have a positive effect on wages in the textile and clothing industry. The sign in parentheses indicates the

\footnotetext{
${ }^{6}$ Bulgaria, Chile, Cyprus, South Korea, Ecuador, Hong-Kong, Hungary, India, Jordan, Macau, Malaysia, Morocco, Philippines, Czech Republic, Romania, Slovakia, Tunisia and Turkey.

7 In reference to the World Bank's classification of October 2008, the IC group represents "high income economies". In our sample, these countries are Korea, Hungary, the Czech Republic and Slovakia.

${ }^{8}$ Except for Mauritius and Turkey.
} 
predicted relationship between each independent variable and the dependant variable. Most of the data used comes from ONUDI ${ }^{9}$ statistics for industrial statistics and COMTRADE ${ }^{10}$ for trade flows.

More specifically, a fragmentation indicator has been created (fragmentation) which relates clothing production to intermediary textile product imports ${ }^{11}$. This study is aligned with those considering the fragmentation process to depend upon intermediary or final product cross exchanges (Fontagné et al. 1995). An upgrading indicator has also been calculated to account for developments in the share of added value in production for each segment; this indicator seeks to capture the effects of product upgrading. Finally, the composite indicators compl and comp2 underline the combined effects of participating in verticalised production processes and upgrading within each sub-sector.

The model may be expressed as follows: ${ }^{12}$

$$
y_{i t}=\alpha+\boldsymbol{v}_{i}+\boldsymbol{\beta}^{\prime} \boldsymbol{x}_{i t}+\varepsilon_{i t}
$$

Let $\boldsymbol{y}_{i t}$ be the dependant variable (relative wage), the vector of explicative variables, for each country $i(i=1, \ldots, 18)$, each year $t(t=1, \ldots, 16), \boldsymbol{\beta}$ ' the vector of coefficients and $\alpha$ the constant term.

According to the "fixed effects" approach, $\boldsymbol{v}_{\boldsymbol{i}}$ is a constant which is specific to each country $i$. It is thus supposed that cross-unit differences may be captured by this term, and $\varepsilon_{i t}$ the error term. According to the "random effects" approach, $\boldsymbol{v}_{\boldsymbol{i}}$ is a random shock characterising the $i^{s t}$ observation and constant over time, and $\varepsilon_{i t}$ the error term. The model is estimated using the generalised least squares method (GLS).

\footnotetext{
${ }^{9}$ ONUDI, Indstat 2008, Rev2, Rev3.

${ }^{10}$ United Nations Commodity Trade Statistics Database, 2008. The trade statistics relating to the textile and clothing sector enable us to differentiate among stages of production. It is thus possible to identify finished product exports (SITC rev3, category 84) and intermediary product exports (SITC rev3, category 65).

${ }_{11}$ The input-output tables recommended by certain authors (Fontagné 1991) are another means of understanding these phenomena. However, this method is not used here due to a lack of statistical data.

${ }^{12}$ Fixed Effect or Random Effect are employed depending on the Hausman test results. These results are available from the authors upon request.
} 
Table 1. List of model's explicative variables

\begin{tabular}{|c|c|c|c|}
\hline Variables & Definition & Predicted sign & Variable role \\
\hline \multicolumn{4}{|c|}{ International specialisation } \\
\hline export-text & $\begin{array}{l}\text { Share of country's intermediary product exports } \\
\text { in total exports to the rest of the world }\end{array}$ & $(+)$ & \multirow[b]{2}{*}{ The goal is to capture the impact of countries' international specialisations on relative wage levels. } \\
\hline export-cloth & $\begin{array}{l}\text { Share of country's final product exports in total } \\
\text { exports to the rest of the world, }\end{array}$ & $(+)$ & \\
\hline \multicolumn{4}{|c|}{ Increase in production capacity and upgrading } \\
\hline equipment-text & $\begin{array}{l}\text { Share of textile machine imports in clothing } \\
\text { sector added value }\end{array}$ & $(+)$ & \multirow{2}{*}{$\begin{array}{l}\text { Equipment used in the early stages of production is distinguished from that needed to produce final products. } \\
\text { Imports of clothing production machines suggest a country's specialisation downstream in the production process } \\
\text { and may be a factor in reducing wage gaps between the textile and clothing sector and the manufacturing sector. }\end{array}$} \\
\hline equipment-cloth & $\begin{array}{l}\text { Share of clothing machine imports in clothing } \\
\text { sector added value }\end{array}$ & $(+)$ & \\
\hline upgrading- cloth & Share of added value in clothing production & $(+)$ & \multirow{2}{*}{$\begin{array}{l}\text { The indicator capturing the upgrading phenomenon represents the share of added value in production. It is predicted } \\
\text { that higher specialisation in terms of a sector's share in manufacturing added value will have an overall positive } \\
\text { effect on relative wages. }\end{array}$} \\
\hline upgrading-text & Share of added value in textile production & $(+)$ & \\
\hline \multicolumn{4}{|c|}{ Specialisation and performance of local production systems } \\
\hline added-value-text & $\begin{array}{l}\text { Textile sector's share of added value in } \\
\text { manufacturing sector's added value }\end{array}$ & $(+)$ & \multirow{4}{*}{$\begin{array}{l}\text { The performance of local production systems is classed by testing, first, the impact of specialisation through the } \\
\text { share of added value in relative wages, and then by taking into account the influence of labour factor }{ }^{13} \text {. It is } \\
\text { predicted that greater specialisation in terms of the share in manufacturing added value will have an overall positive } \\
\text { effect on relative wages. }\end{array}$} \\
\hline added-value-cloth & $\begin{array}{l}\text { Clothing sector's share of added value in } \\
\text { manufacturing sector's added value }\end{array}$ & $(+)$ & \\
\hline employ-text & $\begin{array}{l}\text { Share of textile sector employment in total } \\
\text { manufacturing sector employment }\end{array}$ & $\begin{array}{l}\text { Employ-text_IC }(+/-) \\
\text { Employ-text_EC(+/-) }\end{array}$ & \\
\hline employ-cloth & $\begin{array}{l}\text { Share of clothing sector employment in total } \\
\text { manufacturing sector employment }\end{array}$ & $\begin{array}{l}\text { Employ-cloth_IC }(+/-) \\
\text { Employ-cloth_EC(+/-) }\end{array}$ & \\
\hline productivity-text & $\begin{array}{l}\text { Relative work productivity in textile sector } \\
\text { compared with manufacturing sector work } \\
\text { productivity }\end{array}$ & $(+)$ & \multirow[t]{2}{*}{ Improved work productivity in both stages of production should have a positive impact on wages. } \\
\hline productivity-cloth & $\begin{array}{l}\text { Relative work productivity in clothing sector } \\
\text { compared with manufacturing sector work } \\
\text { productivity }\end{array}$ & $(+)$ & \\
\hline \multicolumn{4}{|r|}{ Fragmentation process } \\
\hline fragmentation & $\begin{array}{l}\text { Share of textile product imports out of clothing } \\
\text { product imports }\end{array}$ & $(+/-)$ & $\begin{array}{l}\text { This indicator classes the fragmentation process in which the sample countries are involved and informs us to what } \\
\text { extent the production of local clothing items is dependent on foreign suppliers. }\end{array}$ \\
\hline compl & Fragmentation*upgrading-cloth & $(+/-)$ & This variable expresses the combined effects of fragmentation and upgrading on the clothing segment. \\
\hline comp2 & Fragmentation*upgrading-text & $(+/-)$ & This variable expresses the combined effects of fragmentation and upgrading on the textile segment. \\
\hline
\end{tabular}

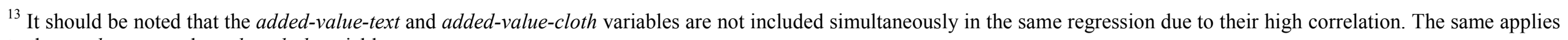
to the employ-text and employ-cloth variables.
} 


\subsection{Estimation results}

The results are shown in tables 2 and 3. The overall dependent variable (wage-textile-clothing) for the textile and clothing sector was addressed first. It was necessary to measure the impact of the independent variables representing the industry as a whole (textile-clothing) (table 2). Next, in order to achieve more precise results, a test was carried out on the sensitivity of overall wage (wage-textile-clothing) to independent variables specific to the textile and clothing segments (table 3). Finally, the effects of all independent sectorial variables on relative clothing and textile wages were studied in order to appreciate the specific characteristics of these two activity segments (table 3 ).

The model's significance level is satisfactory overall, and it appears that each of the four categories of variables used influences the model's overall dependant variable, relative wage wage-textile-clothing, with differentiated effects on the dependent variables wage-text and wagecloth.

Table 2. Effects of model's independent variables on relative wages in the textile and clothing sector (wage-textileclothing).

\begin{tabular}{|c|c|c|c|c|}
\hline \multirow[b]{2}{*}{$\begin{array}{l}\text { fragmentation } \\
\text { compl }\end{array}$} & \multicolumn{4}{|c|}{ Wage-textile-clothing } \\
\hline & $\begin{array}{l}-0.065^{* * *} \\
{[4.46]}\end{array}$ & $\begin{array}{l}-0.048^{* * *} \\
{[3.08]}\end{array}$ & $\begin{array}{l}-0.175^{* * *} \\
{[4.98]}\end{array}$ & $\begin{array}{l}-0.131 \text { *** } \\
{[3.56]}\end{array}$ \\
\hline $\begin{array}{l}\text { equipment-textile-clothing } \\
\text { employment-textile-clothing EC } \\
\text { employment -textile-clothing IC }\end{array}$ & $\begin{array}{l}0.005 \\
{[0.12]} \\
-0.606^{* * *} \\
{[5.42]}\end{array}$ & $\begin{array}{l}-0.014 \\
{[0.31]} \\
-0.660 * * * \\
{[5.98]}\end{array}$ & $\begin{array}{l}-0.003 \\
{[0.08]} \\
-0.550 * * * \\
{[5.15]}\end{array}$ & $\begin{array}{l}-0.025 \\
{[0.55]} \\
-0.620 * * * \\
{[5.82]}\end{array}$ \\
\hline $\begin{array}{l}\text { upgrading-textile-clothing } \\
\text { productivity-textile-clothing }\end{array}$ & $\begin{array}{l}0.318 * * * \\
{[2.77]} \\
0.351 * * * \\
{[7.57]} \\
\end{array}$ & $\begin{array}{l}0.218^{*} \\
{[1.87]} \\
0.296^{* * *} \\
{[6.15]} \\
\end{array}$ & $\begin{array}{l}0.428 * * * \\
{[3.59]} \\
0.390^{* * *} \\
{[8.98]} \\
\end{array}$ & $\begin{array}{l}0.300 * * \\
{[2.45]} \\
0.324 * * * \\
{[6.88]} \\
\end{array}$ \\
\hline $\begin{array}{l}x_{-} \text {cloth } \\
x_{-} \text {text }\end{array}$ & & $\begin{array}{l}0.131 * \\
{[1.97]} \\
0.587 * * * \\
{[3.21]} \\
\end{array}$ & & $\begin{array}{l}0.154 * * \\
{[2.41]} \\
0.490^{* * *} \\
{[2.62]}\end{array}$ \\
\hline Constant & $\begin{array}{l}0.548^{* * *} \\
{[10.38]}\end{array}$ & $\begin{array}{l}0.540 * * * \\
{[10.41]}\end{array}$ & $\begin{array}{l}0.486^{* * *} \\
{[9.67]}\end{array}$ & $\begin{array}{l}0.498^{* * *} \\
{[10.00]}\end{array}$ \\
\hline $\begin{array}{l}\text { Observations } \\
\text { Number of countries } \\
\text { R-squared (within) }\end{array}$ & $\begin{array}{c}282 \\
18 \\
0.40\end{array}$ & $\begin{array}{c}282 \\
18 \\
0.43\end{array}$ & $\begin{array}{c}282 \\
18 \\
0.41\end{array}$ & $\begin{array}{c}282 \\
18 \\
0.44\end{array}$ \\
\hline
\end{tabular}

Absolute value of $t$ statistics in brackets; $*$ significant at $10 \% ; * *$ significant at $5 \% ; * * *$ significant at $1 \%$ 
Table 3. Effects of model's independent variables on relative wages in the textile and clothing sector (wage-textile-clothing).

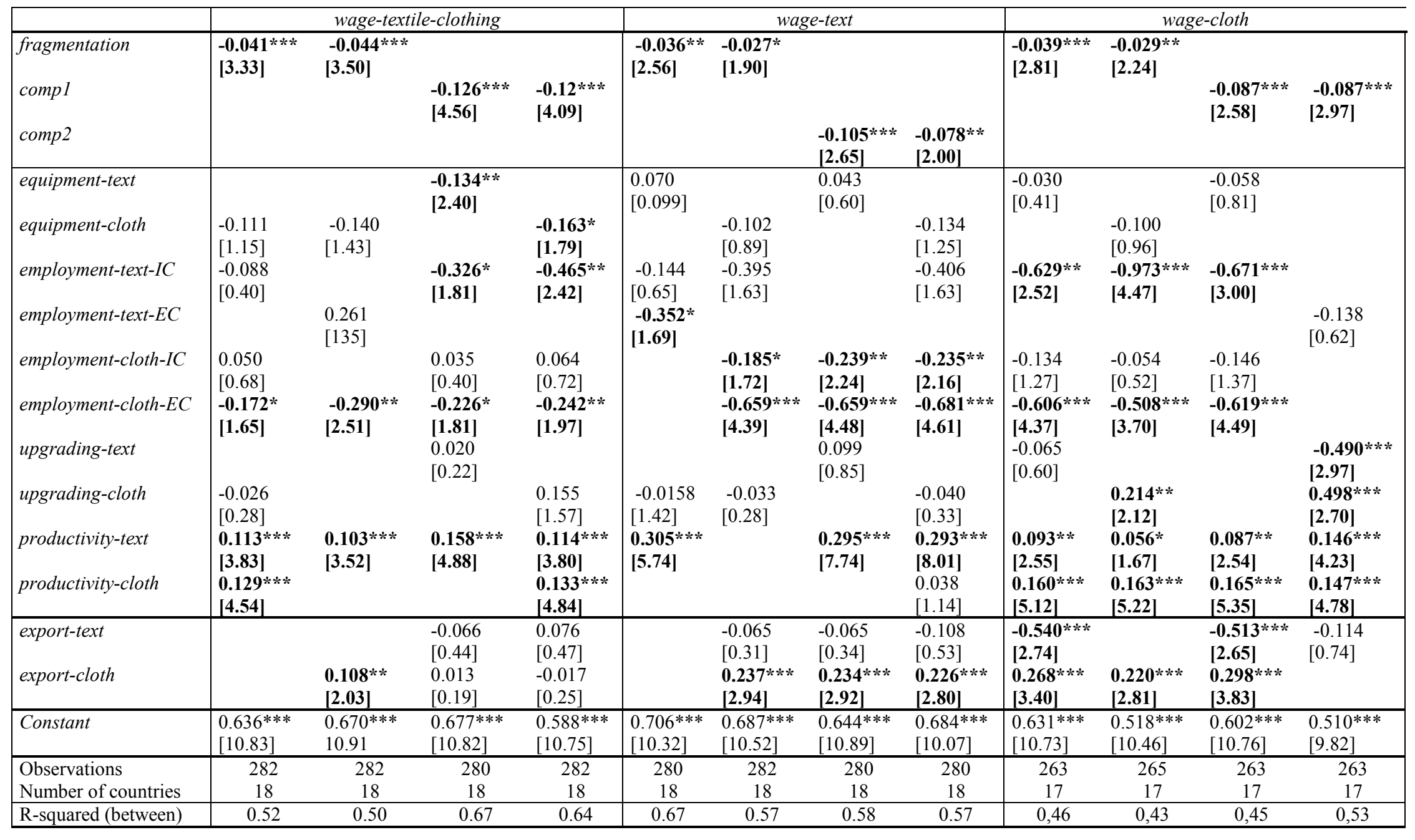

Absolute value of $t$ statistics in brackets; $*$ significant at 10\%; ** significant at $5 \% ; * * *$ significant at $1 \%$ 


\subsubsection{Upgrading efforts fail to offset the negative impact observed for fragmentation variables}

The econometric results reveal the fragmentation indicator's (fragmentation) significant and negative effect on relative wages in this sector (wage-textile-clothing). This negative impact is confirmed for each production segment, with a significant and negative effect for fragmentation on relative wages in the textile segment (wage-text) and in the clothing segment (wage-cloth). This shows that production fragmentation creates a system of dependency on sector intermediate inputs, which prevents the improvement of the relative position of wages in the sector as a whole. Our results thus echo Hayter's (2004) analysis, as well as that of Milberg and von Armin (2006). They are born out by the observation of sectorial statistics underlining, for that period, a tendency towards the depreciation of relative wages, especially in the clothing segment (fig. 1). Moreover, a significant and negative impact is observed for the indicator compl on relative wages in the entire sector (wage-text-clothing) and on relative wages in the clothing sector (wage-cloth), as well as a significant and negative impact for the composite indicator comp2 on relative wages in the textile segment (wage-text). This indicates that upgrading attempts are not significant enough to counterbalance the negative effects of fragmentation processes on relative wages in the sector.

This phenomenon may be explained by two corresponding factors: first, local production systems are unable to create the internal dynamics necessary to sustain development throughout the entire sector. Second, the sector's lack of integration may impede the development of each of its segments.

\subsubsection{An insufficient use of the domestic factors of sector development}

Within a dynamic of virtuous development, emerging countries' participation in verticalised production processes should lead to rapid technological progress and improved productivity. These advancements allow production resources to be reallocated within the specialisation sector (Rodriguez-Clare, 2009) and to the manufacturing sectors generating the most added value. In reality, technology transfers are based on the strategies of leading firms and depend on the positioning of local producers within the network (Unctad, 2003) as well as on industry characteristics.

The negative interaction observed between employment level and relative wages suggests a general increase in lower-skilled labour. In general, employment level has a significant and negative impact on wages throughout the sector (wage-textile-clothing). Particularly in the least developed countries, the employment-clothEC variable has a significant and negative impact on wage-text-clothing, which indicates that becoming highly specialised in downstream segments accentuates unskilled labour, resulting in lower relative wages throughout the sector. This poses a problem given that, for the majority of $E C$ countries, the clothing industry is the main source of unskilled employment. However, the sub-sector analysis suggests that these results should be put into perspective. Since labour is not linked to an upgrading process within these countries, need is essentially concentrated in standardised factors of production. For these countries, the improvement of product quality, just like achieving a more advanced position in the value chain, requires not only higher qualification in production, but also training efforts in service activity, such as management, quality, logistics, etc. Our results reflect those of Gereffi (1999) and Sturgeon et al. (2008). Until now, most $E C$ countries have been protected from international 
competition by the Euromed and $\mathrm{ATC}^{14}$ agreements. Since export markets have been captive, they have not sought to consolidate their managerial capacities. This is evident from the wagecloth variable test results; higher employment level in the clothing industry (employmentclothEC) lowers the relative wage of this same segment (wage-cloth). These results confirm the presence of detrimental effects on worker qualification.

However, the significant and negative impact of the employment-clothIC variable on overall relative wages (wage-textile-clothing) is counter intuitive and may be due to the EC countries' progressive withdrawal from the textile sector throughout the study period, with the exception of Turkey (see fig. 2). The EC countries, generally more specialised downstream in the sector, were those least able to take advantage of their past specialisation to strengthen production capacity throughout the industry.

The absorption capacity of technology imported by local production networks is limited. The tests reveal the negative and significant impact of variables representing investment efforts through machine imports (equipment-text and equipment-cloth) on relative wages throughout the sector (wage-textile-clothing). These observations suggest certain insufficiencies in the transmission of technological knowledge in the case of imported equipment goods (Unctad 2003). Moreover, most of the countries in our sample ${ }^{15}$ display substantial labour productivity delays in the textile and clothing sector as compared with the manufacturing sector as a whole, especially in the clothing segment (fig 1). The significant and positive effects of each segment's productivity variables (productivity-text and productivity-cloth) on relative wages throughout the sector (wage-textile-clothing) should thus be interpreted with caution, since the developments observed for the variables in question are somewhat weak. This mechanism has been described as the "low wage/low productivity trap" (Heintz 2006).

In addition, the positive and significant influence of the upgrading-cloth variable on the clothing industry's relative wage (wage-cloth) shows that the level of added value creation impacts wages positively because it is linked to the position of local producers within the global value chain. This phenomenon may be explained by the development of new activities both in terms of production and with a view to better coordinating the production network (management, logistics, marketing and design...). Such development is necessarily brought about through upgrading. This has allowed the most developed countries to engage in new activities and to increase the quality, reliability and responsiveness of their production systems. This enables a greater share of overall added value to be incorporated into the value chain, as was shown by Kaplinsky and Morris (2007).

The results for the entire sector's relative wage (wage-textile-clothing), however, indicate that, overall, this field has not benefited from the profits anticipated by upgrading efforts, since the upgrading-text and upgrading-cloth variables have no significant effect on wage-textileclothing nor on wage-text. Only the clothing segment displays a significant and positive impact

\footnotetext{
${ }^{14}$ The Agreement on Textile and Clothing disappeared in January 2005, but was prolonged by the EU for China until January 2007.

${ }^{15}$ With the exception of Costa Rica, Malaysia and Mauritius for the IC countries and Jordan for the EC countries. The case of Jordan is particular in the sense that specialisation in the clothing sector occurred later, due to agreements signed with the US and the creation of QIZs. In addition, its productivity begins to rise sharply in 2002.
} 
for the upgrading-cloth variable on wage-cloth, while upgrading-text has a significant and negative impact, which will be discussed further on in this study.

\subsubsection{Specialisation and incomplete sectorial integration}

An intense specialisation in final products leads to a decrease in relative wage throughout the sector. Two variables allow us to assess the level of specialisation in our sample countries. The share of employment in the sector is representative of internal specialisation and the share of exports in this sector out of total manufactured product exports indicates a specialisation in international trade.

It appears that countries which are not active throughout the industry do not generate enough income in the clothing sector. This not only prevents them from developing upstream, but, more importantly, from improving production quality. This indicates that becoming highly specialised in final products does not produce the knock-on effects that might allow countries to develop a strong textile sub-sector and to achieve greater dynamism at the national level throughout the entire industry. The significant and negative impact of the employment-clothEC and employment-clothIC variables on the sector's relative wages (wage-textile-clothing), which indicate the local production system's clothing specialisation, has already been shown.

Clothing product exports (export-cloth) have a significant and positive impact on the sector's relative wage (wage-textile-clothing), on the clothing segment (wage-cloth) and on the textile segment (wage-text). However, the past decrease observed for clothing product exports in the majority of sample countries, with the exclusion of Jordan and Morocco (see table 6), in fact reveals this variable's negative influence on relative wages throughout the textile-clothing industry. This phenomenon is linked to intensified competition and the pressure this exerts on wages. The period of study coincides with the arrival of workers from low-wage countries, such as China and India, within the globalised workplace. This had the dual effect of reinforcing the negotiating power of leading firms and broadening their range of choice for setting up their production activity. Within such verticalised production systems, we no longer find countries competing with one another, but the workers themselves (Kohler 2002; Dash 2005).

Within this framework, specialisation is immiserising in the sense that in order to maintain export levels and market shares, producers achieve their competitiveness through lower costs. This makes countries very vulnerable to international competition (Heintz 2006) and has the effect of deregulating local labour markets (Rodriguez-Clare 2009).

The test results suggest a lack of integration along the value chain. The roles played by the two segments are asymmetrical. In particular, we observe the significant and positive influence of textile segment productivity (productivity-text) on relative wage in the clothing sector (wagecloth), while clothing productivity (productivity-cloth) appears only to affect its own segment. The implicit hierarchy observed in the positioning of these two segments suggests that upstream production benefits the entire sector, while the opposite is not necessarily the case. High performance in the textile segment contributes to improving the relative situations of workers in the downstream segment. When it develops, the textile segment can thus contribute to the dynamism of the clothing industry. Higher quality resources and increased coordination improve production in the clothing sector and bring out certain relative advantages, which foster 
development. In the highly specialised countries (tables 4 and 5), it is evident that the dependency of production in the clothing segment on imported intermediary resources weighs heavily on wages. When producers can obtain supplies locally, they gain increased margins and achieve better growth. Countries controlling their own resources (price and quality) are better positioned for upgrading, and this allows them partially to avoid cost competition in order to focus on quality and production diversification (Kaplinsky and Santos-Paulino 2006).

The lack of reciprocity between the two segments is manifest in the results relating to relative wage in the textile segment (wage-text). They indicate that variables representing an improvement in performance downstream in the clothing sector (productivity-cloth, upgradingcloth, equipment-cloth) have no significant impact on relative wages in textiles ${ }^{16}$ (wage-text). High competitive pressure encourages countries to become more and more specialised in very specific production segments. Income generated by such specialisation is scoured by firm competition constraints and, given the lack of economic policies consciously geared towards the entire sector, the local industry cannot develop as a whole. In the case of Turkey, for example, natural cotton endowments as well as government incentives have allowed the country to develop a competitive national textile and clothing industry, and to be active in each of the textile and clothing's segments (Navaretti et al. 2004).

The significant and negative impact of textile exports (export-text) on wage-cloth indicates that exports of intermediate inputs are damaging to the entire sector. They deprive local clothing producers of raw materials which might be used in domestic production, thereby breaking down the sector's internal coherence.

\section{Concluding remarks}

This analysis has shown that, counter to the assertions of conventional international trade theory, production specialisation connected with the exploitation of relative advantages does not always have positive consequences. Using panel data, this empirical study has brought out this phenomenon in the textile and clothing industry. This observation may be explained by the following elements: first, significant workforce expansion - linked essentially to openness and the liberalisation policies put in place by Asian countries - has intensified competition on a global scale. In the clothing sector in particular, we note the presence of an abundant unqualified workforce and a somewhat inefficient organisation of production. This has caused a loss of competitiveness in this segment as compared with average productivity in the manufacturing industry, despite the fact that, in the past, the clothing activity has been a basis for development and diversification for many developing countries. In fact, the features of production in this segment (labour-intensive, basic technology, contestable markets) seem particularly suited to the constraints of developing countries.

Second, the fragmentation strategies implemented have tended to replace product trade with the trade of factors of production (essentially the unskilled workforce). Within this framework, pressure exerted by distributors favours intensive specialisation in production segments which do not generate a sufficient surplus, not only for financing development in complementary segments

\footnotetext{
${ }^{16}$ Textile activity is relatively underdeveloped in most EC countries, with the exception of India, Indonesia and Turkey (see tables 4 and 5).
} 
(such as textiles) and industrial sectors creating more added value, but also for upgrading within the sector of specialisation. The tendency towards specialisation provoked by the fragmentation of production activity may thus cause certain countries to embark upon immiserising paths.

This article has also identified certain factors leading to damaging blockages in the development of entire sectors in the most specialised countries, as well as in work factor enhancement:

- the disconnection between technology transfers via equipment imports and the dynamic of improvement of workers qualifications indicated by wages;

- the intra-sectorial disjuncture between upstream and downstream production activity.

It should nonetheless be noted that these results are only applicable to the textile and clothing industry, and cannot be applied generally to all sectors in which production processes have been internationally fragmented. As a system in which poorly qualified work constitutes a large share of production costs, the textile and clothing sector is a typical example of the Buyer-DrivenCommodity-Chain activated by "big buyers". The downstream centralisation of decision-making creates an industrial chain with a quasi-hierarchical governance structure: the role played by each stakeholder determines what share of the production network surplus may be claimed by each. A fruitful avenue for future research might involve comparisons with other activities. Carrying out a similar study for sectors generating more added value, such as electronics or automobiles, would allow us to evaluate the importance of sectorial variables and the effects of technology diffusion on workers' relative wages.

\section{Appendix}

Table 4. Share of paid employment in textile and clothing sector as $\%$ of manufacturing employment

\begin{tabular}{|l|rrrr|rrrr|}
\hline & \multicolumn{7}{|c|}{ Clothing } & \multicolumn{4}{c|}{ Textiles } \\
\hline Country & 1990 & \multicolumn{1}{|c}{1995} & \multicolumn{1}{c|}{2004} & \multicolumn{1}{c|}{2005} & 1990 & 1995 & 2004 & 2005 \\
\hline Bulgaria & $7.3 \%$ & $10.7 \%$ & $23.8 \%$ & $22.4 \%$ & $8.5 \%$ & $7.6 \%$ & $5.7 \%$ & $5.4 \%$ \\
Chile & $10.3 \%$ & $9.3 \%$ & $4.4 \%$ & $4.1 \%$ & $8.8 \%$ & $6.4 \%$ & $3.6 \%$ & $3.3 \%$ \\
Colombia & $14.3 \%$ & $14.9 \%$ & $14.2 \%$ & $12.9 \%$ & $10.8 \%$ & $9.9 \%$ & $8.1 \%$ & $8.0 \%$ \\
Costa Rica & $25.3 \%$ & $25.7 \%$ & $13.7 \%$ & $12.8 \%$ & $8.1 \%$ & $6.6 \%$ & $2.6 \%$ & $2.5 \%$ \\
Cyprus & $33.1 \%$ & $21.0 \%$ & $4.2 \%$ & $3.4 \%$ & $5.0 \%$ & $5.6 \%$ & $1.9 \%$ & $1.7 \%$ \\
IC & $8.1 \%$ & $5.7 \%$ & $5.1 \%$ & $3.9 \%$ & $4.6 \%$ & $3.4 \%$ & $2.4 \%$ & $2.4 \%$ \\
Malaysia & $68.1 \%$ & $64.5 \%$ & $58.7 \%$ & $56.9 \%$ & $4.3 \%$ & $4.5 \%$ & $8.1 \%$ & $6.5 \%$ \\
Mauritius & $7.9 \%$ & $6.6 \%$ & $4.1 \%$ & $3.8 \%$ & $11.8 \%$ & $9.5 \%$ & $5.9 \%$ & $5.3 \%$ \\
Korea & $8.3 \%$ & $4.0 \%$ & $2.4 \%$ & $2.0 \%$ & $1.0 \%$ & $0.6 \%$ & $0.5 \%$ & $0.4 \%$ \\
Singapore & $4.0 \%$ & $8.5 \%$ & $5.2 \%$ & $4.7 \%$ & $14.3 \%$ & $7.1 \%$ & $4.5 \%$ & $4.7 \%$ \\
Slovenia & $8.8 \%$ & $12.2 \%$ & $15.7 \%$ & $15.8 \%$ & $20.3 \%$ & $19.3 \%$ & $15.9 \%$ & $16.5 \%$ \\
Turkey & $5.8 \%$ & $3.6 \%$ & $4.9 \%$ & $4.9 \%$ & $13.0 \%$ & $9.3 \%$ & $6.0 \%$ & $5.6 \%$ \\
\hline Ecuador & $2.9 \%$ & $4.3 \%$ & $5.5 \%$ & $5.5 \%$ & $19.3 \%$ & $18.0 \%$ & $15.5 \%$ & $15.5 \%$ \\
India & $11.8 \%$ & $16.5 \%$ & $10.3 \%$ & $10.7 \%$ & $15.7 \%$ & $15.0 \%$ & $12.6 \%$ & $13.4 \%$ \\
Indonesia & $7.4 \%$ & $6.5 \%$ & $13.1 \%$ & $12.5 \%$ & $3.1 \%$ & $3.9 \%$ & $2.4 \%$ & $2.4 \%$ \\
EC Jordan & $22.7 \%$ & $25.9 \%$ & $33.4 \%$ & $33.1 \%$ & $13.3 \%$ & $15.5 \%$ & $8.1 \%$ & $8.8 \%$ \\
Morocco & $18.5 \%$ & $18.3 \%$ & $15.0 \%$ & $15.5 \%$ & $8.9 \%$ & $6.2 \%$ & $3.7 \%$ & $3.4 \%$ \\
Philippines & $24.1 \%$ & $33.1 \%$ & $39.2 \%$ & $51.4 \%$ & $11.1 \%$ & $12.1 \%$ & $13.3 \%$ & $17.5 \%$ \\
\hline Tunisia & & & & & & &
\end{tabular}

Source. ONUDI - Authors' calculations 
Table 5. Share of textile and clothing sector production as \% of manufacturing sector production

\begin{tabular}{|l|rrrr|rrrr|}
\hline & \multicolumn{7}{|c|}{ Clothing } & \multicolumn{5}{c|}{ Textiles } \\
\hline Country & 1990 & 1995 & 2004 & 2005 & 1990 & 1995 & 2004 & 2005 \\
\hline Bulgaria & $4.4 \%$ & $2.6 \%$ & $5.9 \%$ & $4.9 \%$ & $6.3 \%$ & $3.7 \%$ & $3.8 \%$ & $3.5 \%$ \\
Chile & $3.2 \%$ & $3.6 \%$ & $1.0 \%$ & $0.9 \%$ & $3.2 \%$ & $2.5 \%$ & $0.9 \%$ & $0.7 \%$ \\
Colombia & $5.1 \%$ & $4.5 \%$ & $4.1 \%$ & $3.8 \%$ & $7.9 \%$ & $5.9 \%$ & $4.1 \%$ & $3.8 \%$ \\
Costa Rica & $3.7 \%$ & $4.1 \%$ & $2.2 \%$ & $2.1 \%$ & $2.9 \%$ & $3.0 \%$ & $1.4 \%$ & $1.4 \%$ \\
Cyprus & $19.1 \%$ & $11.4 \%$ & $1.9 \%$ & $1.8 \%$ & $3.6 \%$ & $3.5 \%$ & $1 . \%$ & $0.8 \%$ \\
IC & $2.6 \%$ & $1.5 \%$ & $1.0 \%$ & $0.8 \%$ & $3.0 \%$ & $2.3 \%$ & $1.1 \%$ & $1.1 \%$ \\
Malaysia & $38.2 \%$ & $38.4 \%$ & $30.8 \%$ & $29.8 \%$ & $4.4 \%$ & $6.7 \%$ & $7.5 \%$ & $6.0 \%$ \\
Korea & $3.2 \%$ & $3.0 \%$ & $1.5 \%$ & $1.5 \%$ & $7.1 \%$ & $5.4 \%$ & $2.9 \%$ & $2.6 \%$ \\
Singapore & $2.6 \%$ & $0.9 \%$ & $0.4 \%$ & $0.3 \%$ & $0.6 \%$ & $0.3 \%$ & $0.1 \%$ & $0.1 \%$ \\
Slovenia & $2.7 \%$ & $3.0 \%$ & $1.2 \%$ & $1.1 \%$ & $8.4 \%$ & $4.5 \%$ & $2.6 \%$ & $3.3 \%$ \\
Turkey & $4.7 \%$ & $6.5 \%$ & $7.7 \%$ & $8.1 \%$ & $10.8 \%$ & $12.0 \%$ & $12.2 \%$ & $13.3 \%$ \\
\hline Ecuador & $1.6 \%$ & $0.7 \%$ & $1.0 \%$ & $1.2 \%$ & $6.3 \%$ & $4.4 \%$ & $2.6 \%$ & $2.4 \%$ \\
India & $2.1 \%$ & $2.6 \%$ & $1.5 \%$ & $1.5 \%$ & $11.5 \%$ & $11.0 \%$ & $6.9 \%$ & $6.9 \%$ \\
Indonesia & $4.7 \%$ & $6.5 \%$ & $3.1 \%$ & $3.4 \%$ & $11.2 \%$ & $12.1 \%$ & $8.6 \%$ & $8.5 \%$ \\
EC Jordan & $2.3 \%$ & $1.5 \%$ & $6.0 \%$ & $5.6 \%$ & $2.5 \%$ & $2.1 \%$ & $1.1 \%$ & $1.0 \%$ \\
Morocco & $7.7 \%$ & $7.9 \%$ & $7.9 \%$ & $6.8 \%$ & $9.2 \%$ & $9.4 \%$ & $4.8 \%$ & $4.2 \%$ \\
Philippines & $4.7 \%$ & $4.0 \%$ & $2.4 \%$ & $2.3 \%$ & $4.7 \%$ & $3.2 \%$ & $1.5 \%$ & $1.3 \%$ \\
Tunisia & $13.8 \%$ & $20.3 \%$ & $24.4 \%$ & $24.4 \%$ & $6.5 \%$ & $7.9 \%$ & $4.9 \%$ & $4.9 \%$ \\
\hline
\end{tabular}

Source. ONUDI - Authors' calculations

Table 6. Share of textile and clothing sector exports as \% of manufacturing exports

\begin{tabular}{|l|rrrr|rrrr|}
\hline & \multicolumn{7}{|c|}{ Clothing } & \multicolumn{5}{c|}{ Textiles } \\
\hline Country & 1990 & 1995 & 2000 & 2005 & 1990 & 1995 & 2000 & 2005 \\
\hline Bulgaria & - & - & $22 \%$ & $21 \%$ & - & - & $2 \%$ & $2 \%$ \\
Chile & $1 \%$ & $1 \%$ & $0.5 \%$ & $0.3 \%$ & $1 \%$ & $1 \%$ & $1 \%$ & $1 \%$ \\
& & & & & & & & \\
Colombia & $27 \%$ & $16 \%$ & $12 \%$ & $12 \%$ & $8 \%$ & $8 \%$ & $6 \%$ & $5 \%$ \\
Costa Rica & $13 \%$ & $7 \%$ & $11 \%$ & $10 \%$ & $6 \%$ & $4 \%$ & $1 \%$ & $1 \%$ \\
IC & $29 \%$ & $20 \%$ & $10 \%$ & $2 \%$ & $11 \%$ & $12 \%$ & $8 \%$ & $1 \%$ \\
Malaysia & $8 \%$ & $4 \%$ & $3 \%$ & $2 \%$ & $2 \%$ & $2 \%$ & $2 \%$ & $1 \%$ \\
Mauritius & $77 \%$ & $75 \%$ & $79 \%$ & $53 \%$ & $4 \%$ & $7 \%$ & $7 \%$ & $5 \%$ \\
Korea & $13 \%$ & $4 \%$ & $3 \%$ & $1 \%$ & $10 \%$ & $11 \%$ & $8 \%$ & $4 \%$ \\
Singapore & $4 \%$ & $1 \%$ & $2 \%$ & $1 \%$ & $2 \%$ & $1 \%$ & $1 \%$ & $0 \%$ \\
Slovenia & - & $9 \%$ & $5 \%$ & $2 \%$ & - & $4 \%$ & $4 \%$ & $3 \%$ \\
Turkey & $37 \%$ & $37 \%$ & $29 \%$ & $19 \%$ & $16 \%$ & $15 \%$ & $16 \%$ & $12 \%$ \\
\hline Ecuador & $17 \%$ & $5 \%$ & $5 \%$ & $4 \%$ & $5 \%$ & $10 \%$ & $10 \%$ & $6 \%$ \\
India & $20 \%$ & $18 \%$ & $18 \%$ & $12 \%$ & $17 \%$ & $19 \%$ & $17 \%$ & $11 \%$ \\
Indonesia & $17 \%$ & $14 \%$ & $13 \%$ & $12 \%$ & $13 \%$ & $11 \%$ & $10 \%$ & $8 \%$ \\
EC Jordan & $2 \%$ & $3 \%$ & $12 \%$ & $34 \%$ & $5 \%$ & $5 \%$ & $4 \%$ & $1 \%$ \\
Morocco & $32 \%$ & $32 \%$ & $49 \%$ & $39 \%$ & $9 \%$ & $7 \%$ & $3 \%$ & $3 \%$ \\
Philippines & $20 \%$ & $14 \%$ & $7 \%$ & $6 \%$ & $3 \%$ & $3 \%$ & $1 \%$ & $1 \%$ \\
Tunisia & $46 \%$ & $53 \%$ & $49 \%$ & $40 \%$ & $5 \%$ & $4 \%$ & $3 \%$ & $4 \%$ \\
\hline
\end{tabular}

Sources. ONUDI and COMTRADE - Authors' calculations 
Fig. 1 Clothing and textile relative wages.
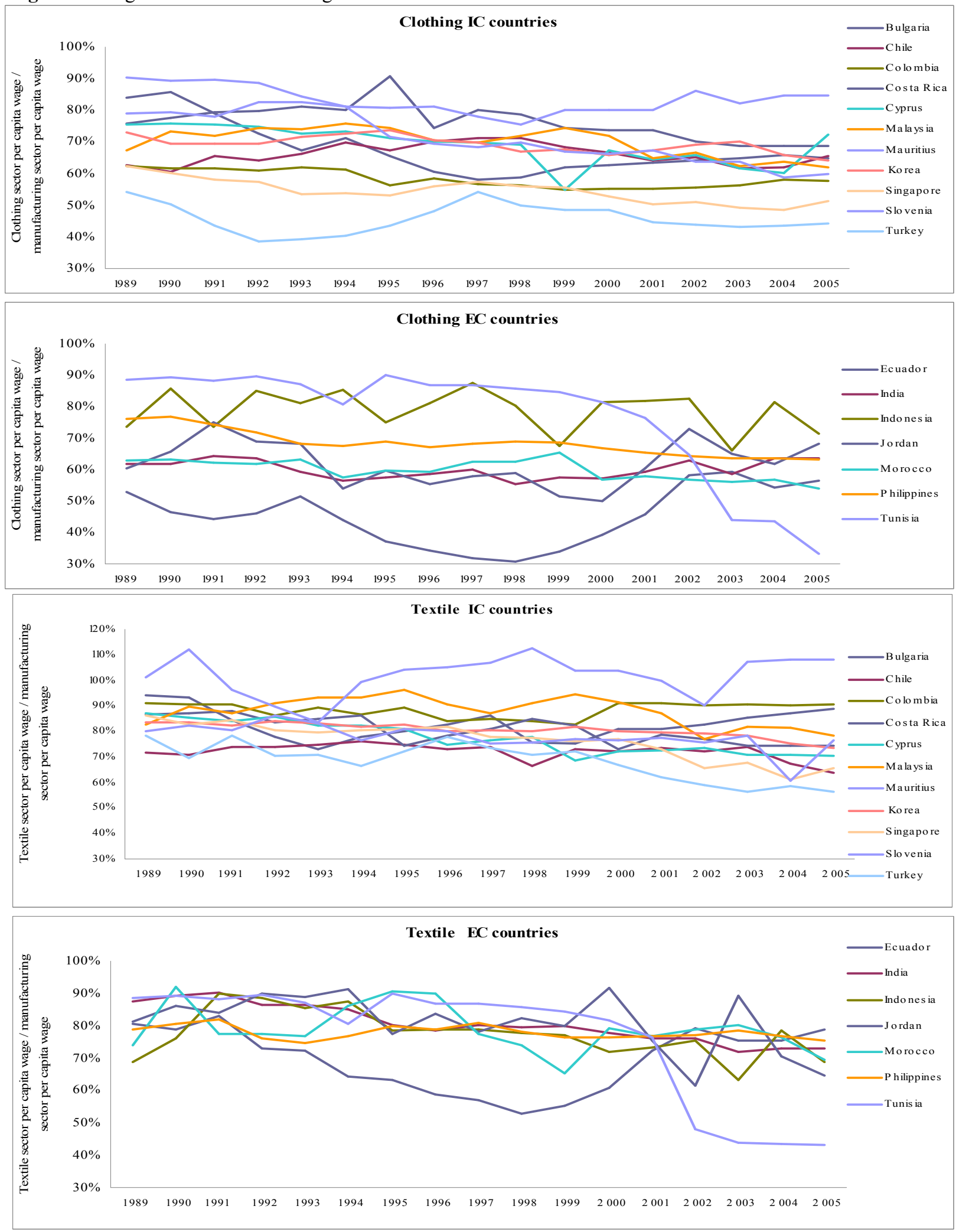

Source. ONUDI - Authors' calculations 
Fig.2 Apparent labour productivity in the textile and clothing sector $(1989=1)$.

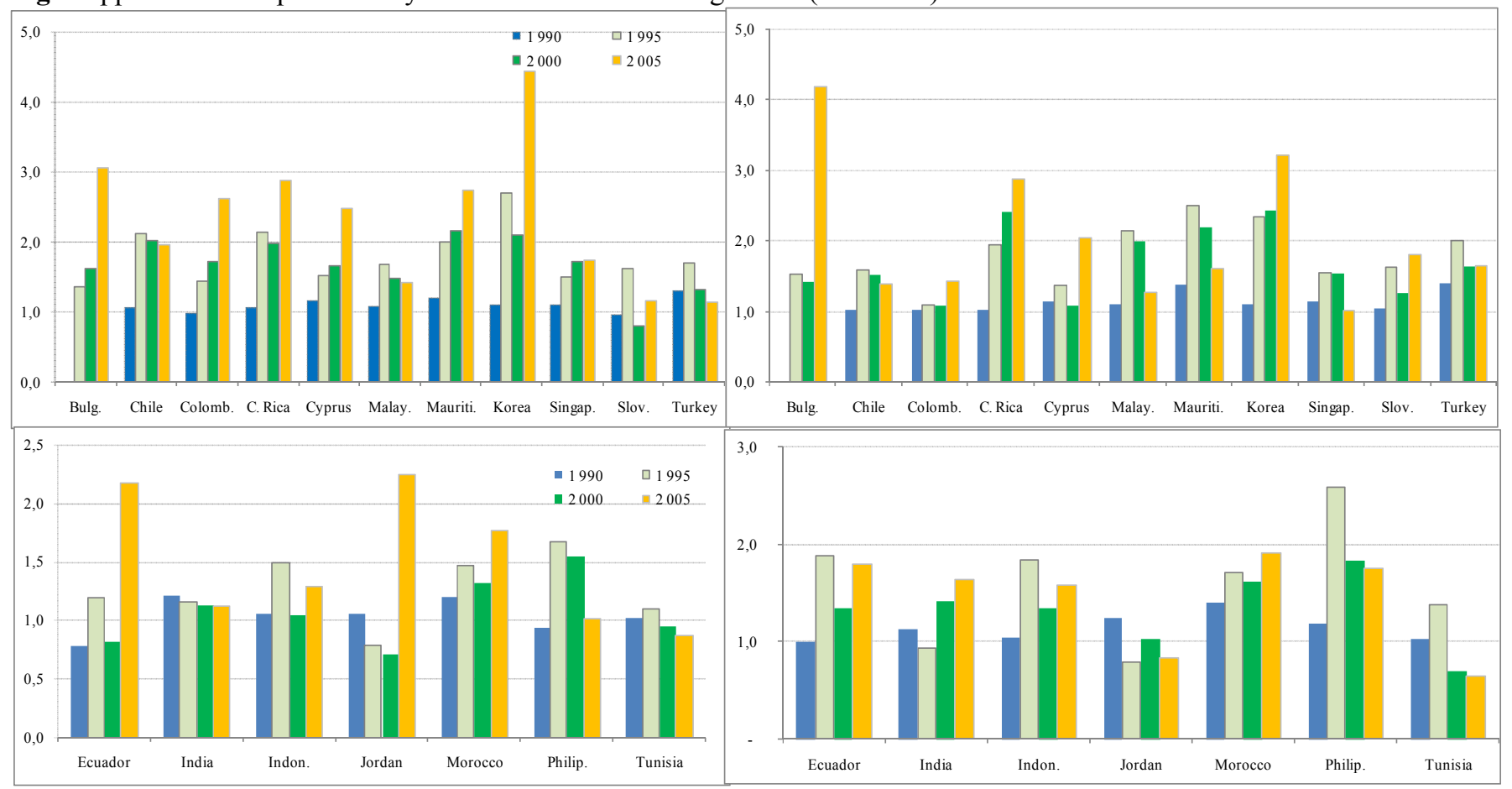

Source. ONUDI - Authors' calculations

\section{References}

Acemoglu, D., Antras, P. \& Helpman, E. (2007). Contract and technology adoption, American Economic Review,.3, 916-943

Ando, M., Arndt, S.W. \&. Kimura, F. (2006). Production networks in East Asia: strategic behavior by japanese and U.S. firms. Paper presented at Japan Center for Economic Research Conférence:Kobe.

Antràs, P. (2003). Firms, contracts and trade structure. The Quarterly Journal of economics. 118(4), 1375-1418

Antràs, P. \& Helpman, E. (2004). Global sourcing. Journal of Political Economy. 112, 552-580.

Antràs P., Garicano, L. \& Rossi-Hansberg, E. (2006). Offshoring in a Knowledge Economy. Quarterly Journal of Economics, 121(1), 31-77.

Baldone, S., Sdogati, F. \& Tajoli, L. (2007). On some effects of international fragmentation of production on comparative advantages, trade flows and the income of countries. The World Economy, 29, 1756-1780.

Baldwin, R. \& Robert-Nicoud, F. (2007). Offshoring: general equilibrium effects on wages, production and trade. (NBER working paper 12991). Cambridge MA: National Bureau of Economic Research.

Bhagwati, J. (1958). Immiserizing Growth: A Geometrical Note. Review of Economic Studies, 25(3), 201-205.

Bottini, N., Ernst, C. \& Luebker, M. (2007). Offshoring and the labour market: What are the issues?. (Economic and Labour Market Paper 2007/11). Geneva :International Labour Office.

Brenton, P. \& Hoppe, M. (2007). Clothing and export diversification: still a route to growth for low-income countries?.(Policy Research working Paper 4343). Washington DC:The World Bank. 
Dash, S. (2005). Fragmentation in international trade: manufacturing vs services. (working Paper, july). New Delhi:Institute of Integrated Learning and Management.

Deardorff, A. (1998). Fragmentation across cones. (Discussion Paper 427). Michigan:University of Michigan, Research seminar in international economics.

Deardorff, A. (2001). Fragmentation in simple trade models. North American Journal of Economics and Finance, 12(2), 121-137.

Egger, P. (2006). Intermediate goods trade and international wage convergence in Central Europe. Empirica, 33, 181-192.

Egger, P. \& Stehrer, R. (2003). International outsourcing and the skill-specific wage bill in Eastern. The World Economy, 26(1), 61-72.

Ekholm, K. \&. Ullveit-Moe, K.H. (2007). A new look at offshoring and inequality: specialisation versus competition. (CEPR discussion paper 6402). London : Center for Economic Policy Research.

Feenstra, R.C. \&. Hanson, G.H. (1996). Foreigh investment, outsourcing and relative wages. In Feenstra R.C, Grossman GM, Irwin D (Eds). The political economy of trade policy: papers in Honor of Jagdish Bhagwati,. Cambridge MA: MIT Press.

Feenstra, R.C. \& Hanson, G.H. (1997). Foreign direct investment and relative wages : evidence from Mexicos maquiladoras. Journal of international economics, 42, 371-393.

Feenstra, R.C. \& Hanson, G.H. (2001). Global production sharing and rising inequality : a survey of trade and wages. (NBER working paper 8372). Cambridge MA: National Bureau of Economic Research.

Fontagné, L. (1991). Biens intermédiaires et Division Internationale du Travail. Paris : Economica.

Fontagné, L., Freudenberg, M. \& Unal Kesenci, D. (1995). Régionalisation et échanges de biens intermédiaires. (CEPII Document de travail Cepii 95-11). Paris: Centre d'Etudes Prospectives et d'Informations Internationales.

Geishecker, I. \& Görg, H. (2005). Do unskilled workers always lose from fragmentation? North American journal of Economics and Finance, 16, 81-92.

Gereffi, G. (1994). The international economy and economic development. In The Handbook of Economic Sociology. Princeton : Princeton University Press.

Gereffi, G. (1996). Global commodity chains: new form of coordination and control among nations and firms in international industries, Competition and Change, 1(4), 427-439.

Gereffi, G. (1999). International trade and industrial upgrading in the apparel commodity chain. Journal of International Economics, 48(1), 37-70.

Grossman, G. \& Helpman, E. (2004). Managerial incentives and international organization of production. Journal of International Economics, 63(2), 237-262.

Grossman, G. \& Helpman, E. (2005). Outsourcing in a global economy. Review of Economic Studies, 72(1), 135-159.

Grossman, G.M. \& Rossi-Hansberg, E. (2006). The rise of offshoring: its not wine for cloth anymore. In The new Economic Geography : Effects and policy implications. (Jackson Hole Conference, 59-102). Kansas City : Federal Reserve Bank.

Grossman, G.M. \& Rossi-Hansberg, E. (2008). Trading tasks: a simple theory of offshoring. American Economic Review. American Economic Association, vol. 98(5), 1978-97.

Hayter S. (2004). The social dimension of global production systems: a review of the issues. (ILO working paper 25) Geneva: International Labour Organization, policy integration department.

Heintz, J. (2006). Low-wage manufacturing and global commodity chains: a model in the unequal exchange tradition. Cambridge Journal of Economics, 30(4), 507-520. 
Helg, R. \& Tajoli, L. (2004). Patterns of international fragmentation of production and implications for labor markets. (RSIE Discussion Paper 503). Michigan : The Universtiy of Michigan. Research Seminar in International Economics.

Hummels, D., Ishii, J. \& Yi, K. (2001). The nature and growth of vertical specialization in world trade. Journal of International Economics, 54, 75-96.

Jones, R.W \& Kierzkowski, H. (2001). A framework of fragmentation. In Arndt S.W. et Kierzkowski H. (Eds), Fragmentation: new production patterns in the world economy. Oxford : Oxford University Press.

Kaplinsky, R. \& Morris, M. (2007). The structure of supply chains and their implications for export supply. Nairobi: African Economic Research, Consortium (AERC).

Kaplinsky, R. \& Santos-Paulino, A.U. (2006). A disaggregated analysis of EU imports :the implications for the study of patterns of trade and technology. Cambridge Journal of Economics, 30, 587-611.

Kohler, W. (2001). A specific factors view on outsourcing. North American Journal of Economics and Finance, 12, 31-53.

Kohler, W. (2002). The distributional effects of international fragmentation. (working paper 0201). Linz : University of Linz.

Kimura, F. \& Ando, M. (2005). Two-dimensional fragmentation in East Asia: conceptual framework and empirics. International Review of Economics and Finance, 14, 317-348.

Lall, S., Albaladejo, M. \& Zhang, J. (2004). Mapping fragmentation : electronics and automobile in East Asia and Latin America. Oxford Development Studies, 32(3), 447-464.

Mc Kinsey Global Institute (2003). Offshoring : Is it a win-win game?San Francisco: McKinsey.

Milberg, W. (2004). Labour and the globalisation of production. London: Palgrave Macmillan.

Milberg, W. \& Von Armin, R.L. (2006). Us Offshoring: implication for economic growth and income distribution. (SCEPA working paper 2006-3). New York: Schwarz Center for Economic Policy Analysis.

Munch, J.R. and Skaksen, J.R.(2009). Specialization, outsourcing and wages. Review of world economics, 145 (1), 57-73

Nordàs, H.K. (2004). The global textile and clothing industry post the agreement on textile and clothing. (WTO, Discussion Paper ${ }^{\circ} 5$ ), Geneva : World Trade Organization.

Nordàs, H.K. (2008). Vertical specialisation and its determinants. Journal of Development Studies, 44(7), 1037-1053.

Rodriguez-Clare, A. (2009). Offshoring in a ricardian world. (NBER Working Papers 13203). Cambridge MA: National Bureau of Economic Research

Sturgeon, T., Van Biesebroeck, J. \& Gereffi, G. (2008). Value chains, networks, and clusters: reframing the global automotive industry. (MIT IPC Working Paper 08-002). Cambridge MA: The Industrial Massachusetts, Institute of TechnologyPerformance Center.

Sturgeon, T.J. (2006). Conceptualiser le commerce dintégration: le cadre des chaînes de valeur mondiales. Paper presented at the Conference Commerce intégratif entre le Canada et les Etats-Unis, Implications stratégiques. Ottawa

UNCTAD (2003). Rapport sur le commerce et le développement. (UNCTAD/TDR/2003, Nations Unis).

Yi, K. (2003). Can Vertical Specialization Explain the Growth of World Trade? Journal of Political Economy, 111, 52-102.

Zeddies, G. (2007). Determinants of International Fragmentation of Production in the European Union. (IWK Discussion paper15). Halle : Institut Wirtschaftsforschunh. 